\title{
A Study on Development of Pollution Index Models and Multivariate Statistical Analysis for Heavy Metals in the Soils of APIIC, Visakhapatnam
}

\author{
G. V. Satyanarayana*, T. Byragi Reddy**, R. S. S. Srikanth Vemuri*†, K. Suryanarayana Rao* and \\ Manoj Kumar Karnena*** \\ *Department of BS\&H, Vignan's Institute of Engineering for Women, Visakhapatnam, India \\ **Department of Environmental Sciences, Andhra University, Visakhapatnam, India \\ ***Department of Environmental Science, GITAM Institute of Science, GITAM (Deemed to be) University, \\ Visakhapatnam, India \\ †Corresponding author: R. S. S. Srikanth Vemuri; vrsssrikanth@gmail.com
}

Nat. Env. \& Poll. Tech

Website: www.neptjournal.com

Received: 05-02-2020

Revised: 22-02-2020

Accepted: 15-04-2020

Key Words:

Heavy metals

Pollution index model

Soil pollution

Anthropogenic activities

\begin{abstract}
Soil pollution is a worldwide problem caused by both natural and anthropogenic activities. This has resulted in health and physiological problems to both plants and animals. This study investigated heavy metals in soils within the immediate vicinity. Soils from Seven APIIC zones in Visakhapatnam were collected and analysed for physicochemical characteristics and heavy metals. The data obtained were subjected to the pollution index model and multivariate statistical analysis. The data obtained showed that the soils are rich in zinc, and heavy metals are above trace level with a minor positively skewed distribution. The analysis of pollution index, geoaccumulation index and ecological risk factors in soils in all the locations showed that they are mainly contaminated and polluted by $\mathrm{Cd}$ followed by $\mathrm{Zn}$. The mean heavy metal concentrations around APIIC can be arranged in increasing order as $\mathrm{Cr}<\mathrm{Co}<\mathrm{Pb}$ $<\mathrm{Cu}<\mathrm{Cd}<\mathrm{Zn}$. Element pairs such as Zn-Pb, Zn-Cu, Zn-Cd, Pb-Cu, Pb-Cd, Cu-Cr, Cd-Co and CrCo showed strong positive correlation coefficient " $r$ " indicating their association in the study area. The observed concentrations of heavy metals revealed that soil contamination has been increasing and measures must be taken to ensure the adoption of more environment-friendly practices.
\end{abstract}

\section{INTRODUCTION}

Heavy metals are released into the environment by both natural and anthropogenic sources. The chemical weathering of minerals; and the anthropogenic sources that are associated with industrial, agricultural, mining, land disposal of waste, waste incineration, etc. are the major sources of these metals (Guerra et al. 2012). The soil contamination by heavy metals due to these activities are becoming a major concern throughout the world. Heavy metals contamination of topsoil has been a major concern for their toxicity, persistence and recalcitrant nature. Toxicity of these compounds has been reported extensively (Momodu \& Anyakora 2010, Anyakora et al. 2013). They amass over the time in soils, which act as a sink from which these toxicants are discharged into the groundwater and plants and end up through the food chain causing different toxicological impacts. Impacts of raised concentrations of heavy metals to soil capacities, soil microbial composition and microbial development have for some time been accounted for under both field and laboratory conditions (Tyler et al. 1989). Health effects of elevated levels of $\mathrm{Zn}$ are severe vomiting, diarrhoea, bloody urine, liver and kidney failure and anaemia (Fosmire 1990), while excessive
$\mathrm{Pb}$ causes inhibition of haemoglobin synthesis, dysfunction of the kidneys, reproductive systems and cardiovascular system (Ferner 2001). Other effects of $\mathrm{Pb}$ are damage to the gastrointestinal system, mental retardation in children, infertility and abnormalities in pregnancy (Dara 2000). Excess $\mathrm{Cd}$ has been reported to bring about renal dysfunction, anaemia, hypertension, bone marrow disorder, cancer, kidney damage, bronchitis, liver and brain disorder (Dara 2000), while, high concentration of manganese could result in kidney failure, liver and pancreases malfunctioning (Underwood 1977). Human activities in urban areas largely contribute to the contamination of urban soils and this is a major health concern. Iwegbu et al. (2006) reported elevated concentration of $\mathrm{Cd}, \mathrm{Cr}, \mathrm{Cu}, \mathrm{Pb}, \mathrm{Ni}, \mathrm{Co}$ and $\mathrm{Zn}$ in an automobile mechanic workshop soil while Dauda \& Odoh (2012) in their study revealed the high degree of contamination of $\mathrm{Pb}, \mathrm{Cd}$ and $\mathrm{Zn}$ in soil from fuel filling stations in Benue state. In addition, Ubwa et al. (2013) reported high levels of $\mathrm{Cd}, \mathrm{Zn}, \mathrm{Ni}, \mathrm{Cr}$ and $\mathrm{Pb}$ from the soils around the Gboko area. The extent of human impact is now so pervasive and profound, that there is a need to investigate the levels of heavy metals in soils from different anthropogenically influenced sites. The objective of 
this study is to determine the physicochemical characteristics and heavy metals in surface and sub-surface soils from the selected sites in Visakhapatnam.

\section{MATERIALS AND METHODS}

\section{Study Area}

Visakhapatnam is one of the major port cities on the east coast of India. After bifurcation of Andhra Pradesh state in 2014 , this city became its business capital with an area of $550 \mathrm{~km}^{2}$. Seven areas were randomly selected as sampling sites in APIIC zone and located using GPS positions (Table 1). The base map (Fig.1) was prepared from these sampling locations.

\section{Sampling and Preparation}

Soil samples were taken from depths of $0-15 \mathrm{~cm}$. All the soil samples were stored in clean polythene bags and brought to the laboratory. The soil samples were air-dried, ground and passed through $2 \mathrm{~mm}$ sieve for physicochemical and heavy metal analysis.

\section{Physico-Chemical Analysis of Soil Samples}

The soil $\mathrm{pH}$ and conductivity were determined in 1 (soil):5 (water) suspension using HM digital meter-CO-100 and Equip-Tronics EQ-614 respectively. Soil texture and organic carbon were determined by the hydrometer method (Jacob \& Clark 2002) and Walkley-Black wet oxidation method (Nelson \& Sommers 1982) respectively. A factor of 1.72 was multiplied with organic carbon content to determine Soil organic matter.

\section{Heavy Metal Analysis}

For heavy metal $(\mathrm{Zn}, \mathrm{Cr}, \mathrm{Cu}, \mathrm{Cd}, \mathrm{Co}$ and $\mathrm{Pb})$ determination, one gram of soil was digested with $15 \mathrm{~mL}$ of aqua regia at $80^{\circ} \mathrm{C}$ till a transparent solution was obtained (Wen \& Allen 1999). The digested samples were filtered and diluted with de-ionized water up to $50 \mathrm{~mL}$ and analysed for the metals, viz. zinc $(\mathrm{Zn})$, chromium $(\mathrm{Cr})$, copper $(\mathrm{Cu})$, cadmium $(\mathrm{Cd})$, cobalt $(\mathrm{Co})$ and lead $(\mathrm{Pb})$ by atomic absorption spectrophotometer (AAS).

\section{Pollution Index Model}

Contamination factor $\left(\mathbf{C}_{\mathbf{f}}\right)$ : Lacatusu (2000) standards were adopted in the current study for the interpretation of the contamination factor. The factors were used to ascertain the soil contamination levels by heavy metals. The $C_{f}$ is the ratio of the concentration of heavy metals to the background value. These values are in the range of 1-6.

$$
\text { Contamination factor }\left(C_{f}\right)=\frac{C_{m}}{C_{b}}
$$

Where, $C_{m}$ is the concentration of metals and $C_{b}$ is the background value.
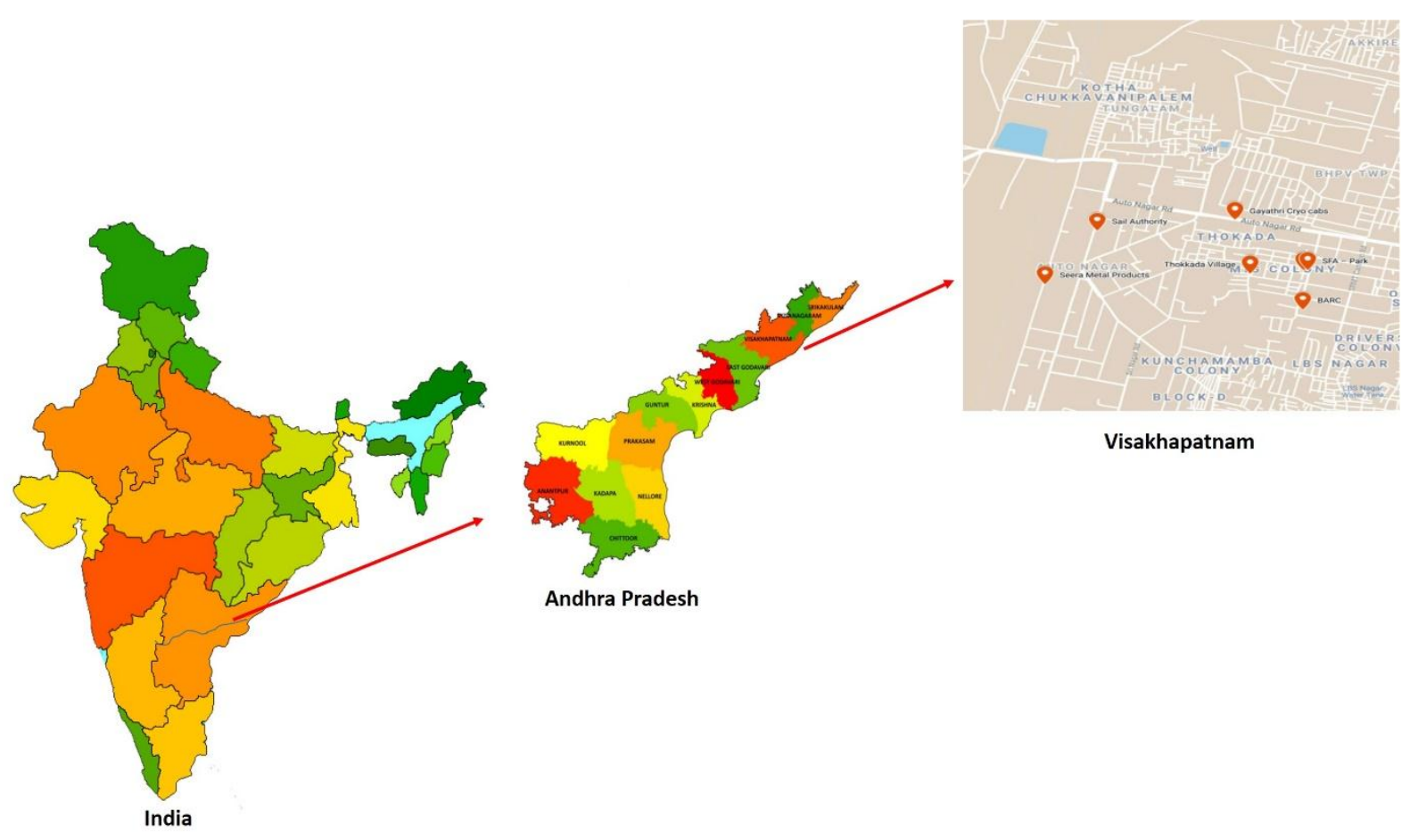

Fig. 1: Location map of the study area. 
Table 1: Sampling sites and GPS positions.

\begin{tabular}{|c|c|c|c|c|}
\hline S.no & Locations & Name & GPS positions & \\
\hline 1 & Seera Metal Products & S1 & N 17.695042 & E 83.185539 \\
\hline 2 & Sail Authority & $\mathrm{S} 2$ & N 17.698512 & E 83.188167 \\
\hline 3 & Gayathri Cryo cabs & $\mathrm{S} 3$ & N 17.699218 & E 83.195095 \\
\hline 4 & BARC & $\mathrm{S} 4$ & N 17.693370 & E 83.198513 \\
\hline 5 & LIG - Park & S5 & N 17.695945 & E 83.198546 \\
\hline 6 & SFA - Park & S6 & N 17.695955 & E 83.198760 \\
\hline 7 & Thokkada Village & S7 & N 17.695727 & E 83.195859 \\
\hline
\end{tabular}

The EGASPIN (2002) target values for heavy metals (Table 2) were taken as the background value for the analysis. The range for the significance of intervals of contamination is given in Table 3.

Pollution Index (PI): It is a measure of the degree of overall contamination in a particular location. Tomlinson et al. (1980) procedure was used for calculating the pollution index (PI) for each location as per Equation 2.

Table 2: Target values for heavy metals (mg/kg).

\begin{tabular}{|lll|}
\hline Metals & $\begin{array}{l}\text { Target values } \\
(\mathrm{mg} / \mathrm{kg})\end{array}$ & $\begin{array}{l}\text { Intervention } \\
\text { values }(\mathrm{mg} / \mathrm{kg})\end{array}$ \\
\hline Iron $(\mathrm{Fe})$ & 38000 & - \\
Zinc $(\mathrm{Zn})$ & 140 & 720 \\
Lead $(\mathrm{Pb})$ & 85 & 530 \\
Cobalt $(\mathrm{Co})$ & 20 & 240 \\
Copper $(\mathrm{Cu})$ & 36 & 190 \\
Chromium $(\mathrm{Cr})$ & 100 & 380 \\
Nickel $(\mathrm{Ni})$ & 35 & 210 \\
Manganese $(\mathrm{Mn})$ & 850 & - \\
Arsenic $(\mathrm{As})$ & 1.0 & 10 \\
Cadmium (cd) & 0.8 & 17 \\
\hline
\end{tabular}

Source: EGASPIN, 2002

Table 3: Significance of intervals of contamination factor/pollution index $\left(\mathrm{C}_{\mathrm{f}} / \mathrm{PI}\right)$.

\begin{tabular}{|ll|}
\hline $\mathrm{C}_{\mathrm{f}} / \mathrm{PI}$ & Significance \\
\hline$<0.1$ & Very slight contamination \\
$0.10-0.25$ & Slight contamination \\
$0.26-0.5$ & Moderate contamination \\
$0.51-0.75$ & Severe contamination \\
$0.76-1.00$ & Very severe concentration \\
$1.1-2.0$ & Slight pollution \\
$2.1-4.0$ & Moderate pollution \\
$4.1-8.0$ & Severe pollution \\
$8.1-16.0$ & Very severe pollution \\
$>16.0$ & Excessive pollution \\
\hline
\end{tabular}

Source: Lacatusu (2000)

$$
\mathrm{PI}=\left(\mathrm{Cf} 1 \times \mathrm{C}_{\mathrm{f}} 2 \times \mathrm{C}_{\mathrm{f}} 3 \times \ldots \ldots \ldots \mathrm{C}_{\mathrm{f}} \mathrm{n}\right)^{1 / \mathrm{n}}
$$

Where, $\mathrm{n}$ is the number of metals and $\mathrm{C}_{\mathrm{f}}$ is the contamination factor. The PI is a potential tool that was used to access environmental pollution.

Geo- Accumulation index (Igeo): Muller (1979) formula was used in this study to calculate the index and the values for the various metals are given in Equation 3.

$$
\mathrm{I}_{\text {geo }}=\log _{2}\left(\mathrm{C}_{\mathrm{n}} / 1.5 \mathrm{~B}_{\mathrm{n}}\right)
$$

Where,

$\mathrm{C}_{\mathrm{n}}=$ Contamination of the heavy metal in the soil.

$\mathrm{B}_{\mathrm{n}}=$ Geochemical background of the element or world average of the element in shale.

Muller proposed seven classes (ranging from 0-6) of the geo-accumulation index to classify the levels of contamination of soils by the metals.

Class $0=\mathrm{I}_{\text {geo }} \leq 0$ (practically uncontaminated)

Class $1=0 \leq \mathrm{I}_{\text {geo }} \leq 0$ (uncontaminated to moderately contaminated)

Class $2=1 \leq \mathrm{I}_{\text {geo }} \leq 2$ (moderately contaminated)

Class $3=2 \leq \mathrm{I}_{\text {geo }} \leq 3$ (moderately to heavily contaminated)

Class $4=3 \leq \mathrm{I}_{\text {geo }} \leq 4$ (heavily contaminated)

Class $5=4 \leq \mathrm{I}_{\text {geo }} \leq 5$ (heavily to extremely contaminated)

Class $6=5 \leq \mathrm{I}_{\text {geo }} \leq 6$ (extremely contaminated)

The values that fall other than 6 of the above classes are considered to be in an open class. In that class, the value of the element is many-folds greater than the background value of the metal (Table 4).

The background value taken is considered from world average value in shale $(\mathrm{mg} / \mathrm{kg})$ of the metals determined in the study are $\mathrm{Fe}=47200, \mathrm{Zn}=95, \mathrm{~Pb}=20, \mathrm{Co}=19, \mathrm{Cu}=$ $45, \mathrm{Cr}=90, \mathrm{Ni}=68, \mathrm{Mn}=850, \mathrm{As}=13$ and $\mathrm{Cd}=0.3 \mathrm{mg} / \mathrm{kg}$.

Ecological risk factor $\left(\mathbf{E}_{\mathbf{r}}\right)$ : Hakanson (1980) suggested the ecological risk factor, which is a quantitative expression of potential ecological risk of the given contamination and 
Table 4: Toxic response factor for calculation of ecological factor calculation.

\begin{tabular}{|ll|}
\hline Metals & Toxic response factor \\
\hline Iron $(\mathrm{Fe})$ & NA \\
Zinc $(\mathrm{Zn})$ & 1 \\
Lead $(\mathrm{Pb})$ & 5 \\
Cobalt $(\mathrm{Co})$ & 5 \\
Copper $(\mathrm{Cu})$ & 5 \\
Chromium $(\mathrm{Cr})$ & 2 \\
Nickel $(\mathrm{Ni})$ & 5 \\
Manganese $(\mathrm{Mn})$ & 1 \\
Arsenic $(\mathrm{As})$ & 10 \\
Cadmium $(\mathrm{cd})$ & 30 \\
\hline
\end{tabular}

NA: Not available

is defined as the ratio of the toxic response factor to the contaminant as given in Equation 4.

$$
\mathrm{E}_{\mathrm{r}}=\mathrm{T}_{\mathrm{r}} \times \mathrm{C}_{\mathrm{f}}
$$

Where, $T_{r}$ is the toxic response factor for a given contaminant and $\mathrm{C}_{\mathrm{f}}$ is the contamination factor. The risk factors are dived into 5 categories.

- $\mathrm{E}_{\mathrm{r}}<40$ (low potential ecological risk)

- $40 \quad \mathrm{E}_{\mathrm{r}}<80$ (moderate potential ecological risk)

- $80 \mathrm{E}_{\mathrm{r}}<160$ (considerable potential ecological risk)

- $160 \mathrm{E}_{\mathrm{r}}<320$ (high potential ecological risk)

- $\mathrm{E}_{\mathrm{r}} 320$ (very high ecological risk)

The aim of the risk factor was originally a diagnostic tool for water pollution control, but currently, we utilized it for accessing the soil quality of a location that is contaminated with heavy metals.

\section{Statistical Analysis}

The analysis of physicochemical characteristics and heavy metal content of soil and plant samples was done in triplicates and the data are presented as mean \pm standard error.
Statistical analysis was done with the help of Microsoft excel computer software programs.

\section{RESULTS AND DISCUSSION}

\section{Soil Physicochemical Properties}

The physicochemical properties of soils are given in Table 5 . The studied soil is slightly (S5, S6) and moderately alkaline (S1, S2, S3, S4, S7). The $\mathrm{pH}$ of the soil is in a range of 7.78.26. Soil electrical conductivity, which is a major indicator of salinity of the soil, was found to be low $(45-135 \mathrm{mS} / \mathrm{cm})$.

The Soil Organic Matter (SOM) which is the storehouse of plant nutrients and mineral recycling (Rattan et al. 2005) was found to be low (0.296-1.37\%) which can be attributed to the sandy texture of the soil.

\section{Heavy Metal Analysis}

Table 5 represents the contents of heavy metals ( $\mathrm{Zn}, \mathrm{Cr}, \mathrm{Cu}$, $\mathrm{Cd}, \mathrm{Co}$ and $\mathrm{Pb}$ ) studied in the soils. The $\mathrm{Zn}, \mathrm{Cr}, \mathrm{Cu}$ and $\mathrm{Co}$ are required for plants for metabolic activities (Jolly et al. 2013). They ranged from 10.8 to $227.9,0.01$ to $41.4,1.9$ to 78.9 and 10.5 to $20.8 \mathrm{mg} / \mathrm{kg}$ respectively. $\mathrm{Cd}$ and $\mathrm{Pb}$, which are known toxins and carcinogens (Rajaganapathy et al. 2011), ranged from 24.5 to 71.5 and 0.79 to $51.8 \mathrm{mg} / \mathrm{kg}$. Although extensive use of agrochemicals is prevalent in Visakhapatnam posing a severe risk of heavy metal contamination of soil, the levels of heavy metals in studied soils were below the various maximum permissible limits (Table $6 \& 7$ ). This might be due to leaching of metals to lower soil layers, due to the sandy texture of soil and precipitation. The soil heavy metal contents observed in the present study were at similar levels to the heavy metals observed in soil by Dheri et al. (2007).

\section{Pollution Index Model}

Zn: PI/ $\mathrm{C}_{\mathrm{f}}$ values vary from 0.07 to 1.63 in different samples. Sample $\mathrm{S} 7$ shows very slight contamination whereas samples S3 and S4 show slight pollution and the remaining samples

Table 5: Physico-chemical properties of soils.

\begin{tabular}{|c|c|c|c|c|c|c|c|c|c|}
\hline Sample & $\mathrm{pH}$ & $\begin{array}{l}\text { Electrical conductance } \\
\text { (mmhos) }\end{array}$ & $\begin{array}{l}\text { Organic } \\
\text { carbon } \%\end{array}$ & $\begin{array}{l}\mathrm{Zn} \\
\mathrm{mg} / \mathrm{kg}\end{array}$ & $\begin{array}{l}\mathrm{Pb} \\
\mathrm{mg} / \mathrm{kg}\end{array}$ & $\begin{array}{l}\mathrm{Cu} \\
\mathrm{mg} / \mathrm{kg}\end{array}$ & $\begin{array}{l}\mathrm{Cd} \\
\mathrm{mg} / \mathrm{kg}\end{array}$ & $\begin{array}{l}\mathrm{Cr} \\
\mathrm{mg} / \mathrm{kg}\end{array}$ & $\begin{array}{l}\mathrm{Co} \\
\mathrm{mg} / \mathrm{kg}\end{array}$ \\
\hline 1 & 8.26 & 124 & 0.558 & 68.7 & 20.9 & 78.9 & 36.6 & 36.4 & 10.5 \\
\hline 2 & 8.05 & 98.7 & 0.93 & 34.1 & 8.3 & 22.1 & 41.7 & 41.4 & 20.8 \\
\hline 3 & 8.23 & 79 & 0.679 & 227.9 & 4.8 & 23.7 & 33.8 & 10.2 & 15.3 \\
\hline 4 & 7.94 & 138 & 1.37 & 152.3 & 51.8 & 48.9 & 71.5 & 10.9 & 15.1 \\
\hline 5 & 7.7 & 87 & 1.051 & 103.9 & 43.8 & 9.2 & 89 & 5.33 & 15.6 \\
\hline 6 & 7.74 & 45 & 0.456 & 35.4 & 5.8 & 7.19 & 50.5 & 0.01 & 20.6 \\
\hline 7 & 8.22 & 61.8 & 0.296 & 10.84 & 0.79 & 1.9 & 24.5 & 2.58 & 10.9 \\
\hline
\end{tabular}


Table 6: Contamination Factor/pollution Index for heavy metals for various stations.

\begin{tabular}{|llllllll|}
\hline Metal & Station 1 & Station 2 & Station 3 & Station 4 & Station 5 & Station 6 & Station 7 \\
\hline $\mathrm{Zn}$ & 0.490714 & 0.243571 & 1.627857 & 1.087857 & 0.742143 & 0.252857 & 0.077429 \\
$\mathrm{~Pb}$ & 0.245882 & 0.097647 & 0.056471 & 0.609412 & 0.515294 & 0.068235 & 0.009294 \\
$\mathrm{Cu}$ & 2.191667 & 0.613889 & 0.658333 & 1.358333 & 0.255556 & 0.199722 & 0.052778 \\
$\mathrm{Cd}$ & 45.75 & 52.125 & 42.25 & 89.375 & 111.25 & 63.125 \\
$\mathrm{Cr}$ & 0.364 & 0.414 & 0.102 & 0.109 & 0.0533 & 0.0001 & 0.0258 \\
$\mathrm{Co}$ & 0.525 & 1.04 & 0.765 & 0.755 & 0.78 & 1.03 \\
\hline
\end{tabular}

Table 7: Geoaccumulation index at different stations.

\begin{tabular}{|llllllll|}
\hline Metal & Station 1 & Station 2 & Station 3 & Station 4 & Station 5 & Station 6 & Station 7 \\
\hline $\mathrm{Zn}$ & 0.145114 & 0.072029 & 0.481389 & 0.3217 & 0.219466 & 0.074775 & 0.022897 \\
$\mathrm{~Pb}$ & 0.209697 & 0.083277 & 0.04816 & 0.519727 & 0.43946 & 0.058193 & 0.007926 \\
$\mathrm{Cu}$ & 0.351836 & 0.09855 & 0.105684 & 0.218058 & 0.041025 & 0.032062 \\
$\mathrm{Cd}$ & 24.48133 & 27.89267 & 22.60844 & 47.82556 & 59.53111 & 33.77889 & 16.008473 \\
$\mathrm{Cr}$ & 0.081159 & 0.092307 & 0.022742 & 0.024303 & 0.011884 & $2.23 \mathrm{E}-05$ & 0.005752 \\
$\mathrm{Co}$ & 0.110895 & 0.219677 & 0.161589 & 0.159477 & 0.164758 & 0.217565 & 0.115119 \\
\hline
\end{tabular}

show moderate contamination. Geoaccumulation index of $\mathrm{Zn}$ in all samples indicates that soil has moderate contamination. An ecological risk factor is very low in all samples.

Pb: PI values vary between 0.01 and 0.52 . Severe contamination to soil happened by $\mathrm{Pb}$ in samples $\mathrm{S} 4$ and $\mathrm{S} 5$. Negligible distribution occurred in sample S7. According to geoaccumulation index, the soil is not exclusively contaminated by $\mathrm{Pb}$ in all samples. Ecological risk factor through $\mathrm{Pb}$ is low in all samples.

Cu: Contamination factor varies from 0.05 to 2.19. Moderate pollution is caused by $\mathrm{Cu}$ in sample $\mathrm{S} 1$, and slight pollution observed in sample S4. Soils in all the stations show moderate contamination by $\mathrm{Cu}$. Low potential risk factor observed for all soils.

Cd: Excessive pollution is caused by $\mathrm{Cd}$ in all stations. The PI values vary from 30 to 89 . These high values are due to welding operated small-scale engineering workshops located near the stations. Geoaccumulation index suggests that soils in all the locations are extremely contaminated by $\mathrm{Cd}$. Ecological risk factor values exist in terms of thousands. It clearly shows that these soils are in very high ecological risk. These soils are not at all suitable for cultivation as well as a living.

Cr: Pollution index suggests that soils are contaminated from slight to the severe condition in observed locations. Geoaccumulation index also suggests that soils in all locations are uncontaminated by $\mathrm{Cr}$. Ecological risk factor is negligible in case of $\mathrm{Cr}$.

Co: Pollution index values vary from 0.5 to 1.04 . Severe contamination of soil was observed by cobalt in all locations, particularly in samples S2 and S6. Geoaccumulation index shows moderate contamination by Co to soils in all samples. Low potential toxic response factor was observed in all locations.

\section{Statistical Analysis}

The standard statistical analysis (mean, standard deviation, skewness, kurtosis) carried out to describe the physicochemical characteristics and heavy metals contents in the soil is presented in Tables 8 and 9.

Effect of pH: As per the US Department of Agriculture (USDA 1993), samples S5 and S6 are slightly alkaline and samples S1, S2, S3, S4 and S7 are moderately alkaline. Positive correlation was obtained for $\mathrm{pH}$ with $\mathrm{EC}(\mathrm{r}=0.22)$, $\mathrm{Zn}(\mathrm{r}=0.11), \mathrm{Cu}(\mathrm{r}=0.41)$ and $\mathrm{Cr}(\mathrm{r}=0.43)$. Higher $\mathrm{pH}$ value indicates a low value of organic carbon (McIntosh \& Allen 1993). This is clear when observing samples S1 and S4.

Effect of electrical conductance (EC): EC values vary between 45 mmhos and 138 mmhos. Higher value was observed in the sample S4 and lower value in sample S6. Higher EC values indicate the availability of various salts in the soil and also shows that leaching of soil leads to contamination of groundwater. The positive correlation was obtained with all parameters except Co $(r=-0.29)$, which indicates that $\mathrm{EC}$ is interdependent on all parameters except cobalt.

Effect of organic carbon (OC): OC varies in the range of $0.291 .37 \%$. Sample S4 has a higher OC value of $1.37 \%$, whereas sample S7 has a lower value of $0.29 \%$. The data in 
Table 8: Statistical analysis.

\begin{tabular}{|c|c|c|c|c|c|c|c|c|c|}
\hline & $\mathrm{pH}$ & $\begin{array}{l}\text { EC } \\
\text { mmhos }\end{array}$ & $\begin{array}{l}\text { OC } \\
\%\end{array}$ & $\begin{array}{l}\mathrm{Zn} \\
\mathrm{mg} / \mathrm{kg}\end{array}$ & $\begin{array}{l}\mathrm{Pb} \\
\mathrm{mg} / \mathrm{kg}\end{array}$ & $\begin{array}{l}\mathrm{Cu} \\
\mathrm{mg} / \mathrm{kg}\end{array}$ & $\begin{array}{l}\mathrm{Cd} \\
\mathrm{mg} / \mathrm{kg}\end{array}$ & $\begin{array}{l}\mathrm{Cr} \\
\mathrm{mg} / \mathrm{kg}\end{array}$ & $\begin{array}{l}\mathrm{Co} \\
\mathrm{mg} / \mathrm{kg}\end{array}$ \\
\hline Minimum & 7.7 & 45 & 0.296 & 10.84 & 0.79 & 1.9 & 24.5 & 0.01 & 10.5 \\
\hline Maximum & 8.26 & 138 & 1.37 & 227.9 & 51.8 & 78.9 & 89 & 41.4 & 20.8 \\
\hline Median & 8.05 & 87 & 0.679 & 68.7 & 8.3 & 22.1 & 41.7 & 10.2 & 15.3 \\
\hline Mean & 8.02 & 90.5 & 0.763 & 90.45 & 19.46 & 27.41 & 49.66 & 15.26 & 15.54 \\
\hline Standard deviation & 0.2344 & 32.87 & 0.374 & 77.37 & 20.44 & 27.53 & 22.89 & 16.67 & 4.092 \\
\hline Skewness & -0.4367 & 0.170 & 0.501 & 0.995 & 0.943 & 1.290 & 0.947 & 1.035 & 0.157 \\
\hline Kurtosis & -1.764 & -0.87 & -0.61 & 0.217 & -0.98 & 1.056 & -0.09 & -0.82 & -1.19 \\
\hline Standard error & 0.2333 & 1.754 & 2.272 & 2.262 & 2.355 & 1.505 & 2.348 & 1.144 & 2.365 \\
\hline Standard error of mean & 0.0886 & 12.42 & 0.142 & 29.25 & 7.738 & 10.40 & 8.652 & 6.299 & 1.547 \\
\hline Variance & 0.0550 & 1081 & 0.140 & 5986 & 419.2 & 757.7 & 524.0 & 277.8 & 16.74 \\
\hline Coefficience of variation & 2.9233 & 36.33 & 49.07 & 85.54 & 105.2 & 100.4 & 46.10 & 109.2 & 26.33 \\
\hline
\end{tabular}

Table 9: Correlation matrix for soil parameters.

\begin{tabular}{|c|c|c|c|c|c|c|c|c|c|}
\hline Correlation & $\mathrm{pH}$ & $\begin{array}{l}\text { EC } \\
\text { mmhos }\end{array}$ & $\begin{array}{l}\mathrm{OC} \\
\%\end{array}$ & $\begin{array}{l}\mathrm{Zn} \\
\mathrm{mg} / \mathrm{kg}\end{array}$ & $\begin{array}{l}\mathrm{Pb} \\
\mathrm{mg} / \mathrm{kg}\end{array}$ & $\begin{array}{l}\mathrm{Cu} \\
\mathrm{mg} / \mathrm{kg}\end{array}$ & $\begin{array}{l}\mathrm{Cd} \\
\mathrm{mg} / \mathrm{kg}\end{array}$ & $\begin{array}{l}\mathrm{Cr} \\
\mathrm{mg} / \mathrm{kg}\end{array}$ & $\begin{array}{l}\mathrm{Co} \\
\mathrm{mg} / \mathrm{kg}\end{array}$ \\
\hline $\mathrm{pH}$ & 1.0000 & 0.2204 & -0.3988 & 0.1120 & -0.4636 & 0.4155 & -0.8170 & 0.4289 & -0.5961 \\
\hline $\mathrm{EC}$ mmhos & 0.2204 & 1.0000 & 0.6862 & 0.3217 & 0.6769 & 0.8216 & 0.2798 & 0.5677 & -0.2988 \\
\hline $\mathrm{OC} \%$ & -0.3988 & 0.6862 & 1.0000 & 0.4546 & 0.8400 & 0.2392 & 0.7539 & 0.1484 & 0.2498 \\
\hline $\mathrm{Zn} \mathrm{mg/kg}$ & 0.1120 & 0.3217 & 0.4546 & 1.0000 & 0.3313 & 0.2268 & 0.2249 & -0.1528 & -0.0818 \\
\hline $\mathrm{Pb} \mathrm{mg} / \mathrm{kg}$ & -0.4636 & 0.3217 & 0.8400 & 0.3313 & 1.0000 & 0.3525 & 0.8623 & -0.0609 & -0.1148 \\
\hline $\mathrm{Cu} \mathrm{mg/kg}$ & 0.4155 & 0.8216 & 0.2392 & 0.2268 & 0.3525 & 1.0000 & -0.0512 & 0.6130 & -0.4159 \\
\hline $\mathrm{Cd} \mathrm{mg/kg}$ & -0.8170 & 0.2798 & 0.7539 & 0.2249 & 0.8623 & -0.0512 & 1.0000 & -0.2549 & 0.2518 \\
\hline $\mathrm{Cr} \mathrm{mg} / \mathrm{kg}$ & 0.4289 & 0.5677 & 0.1484 & -0.1528 & -0.0609 & 0.6130 & -0.2549 & 1.0000 & 0.0370 \\
\hline Co $\mathrm{mg} / \mathrm{kg}$ & -0.5961 & -0.2988 & 0.2498 & -0.0818 & -0.1148 & -0.4159 & 0.2518 & 0.0370 & 1.0000 \\
\hline
\end{tabular}

Table 8 clearly indicate that organic carbon is strongly interdependent on $\mathrm{Pb}(\mathrm{r}=0.84)$ and $\mathrm{Cd}(\mathrm{r}=0.75)$ and moderately correlate with $\mathrm{Zn}(\mathrm{r}=0.45), \mathrm{Cu}(\mathrm{r}=0.24)$ and $\mathrm{Co}(\mathrm{r}=0.25)$, whereas weakly interdependent on $\mathrm{Cr}(\mathrm{r}=0.15)$. A negative correlation was observed with $\mathrm{pH}(\mathrm{r}=-0.39)$ which shows that organic carbon oppositely dependent on $\mathrm{pH}$.

\section{Analysis of Heavy Metals}

Effect of Zn: Amount of $\mathrm{Zn}$ present in given samples varies between $10.84 \mathrm{mg} / \mathrm{kg}$ and $227.9 \mathrm{mg} / \mathrm{kg}$. Sample S7 has lower value of $10.84 \mathrm{mg} / \mathrm{kg}$ and sample S3 a higher value of $227.9 \mathrm{mg} / \mathrm{kg}$. The positive correlation obtained with all parameters except $\mathrm{Cr}$ and $\mathrm{Co}$ even though the correlation is weakly interdependent on $\mathrm{pH}, \mathrm{EC}, \mathrm{OC}, \mathrm{Pb}, \mathrm{Cd}$ and $\mathrm{Cu}$

Effect of Pb: Amount of $\mathrm{Pb}$ present in given samples varies from $0.79 \mathrm{mg} / \mathrm{kg}$ to $51.8 \mathrm{mg} / \mathrm{kg}$. In sample $\mathrm{S} 7$ have lowest value $(0.79 \mathrm{mg} / \mathrm{kg})$ whereas sample $\mathrm{S} 4$ contains the highest value of $51.8 \mathrm{mg} / \mathrm{kg}$. A positive correlation was observed with $\mathrm{EC}, \mathrm{OC}, \mathrm{Zn}, \mathrm{Cu}$ and $\mathrm{Cd}$ whereas a negative correlation with $\mathrm{Cr}$ and $\mathrm{Co}$. Among $\mathrm{EC}, \mathrm{OC}, \mathrm{Zn}, \mathrm{Cu}$ and $\mathrm{Cd}, \mathrm{OC}$ is strongly correlated with $\mathrm{Pb}(\mathrm{r}=0.84)$. In the study areas, due to the presence of automobile service centres fuel effluent wastage with $\mathrm{Pb}$ and organic carbon enters into the soil. In fuels, $\mathrm{Pb}$ and $\mathrm{Cd}$ are added as anti-knocking agents hence there is a strong correlation between $\mathrm{Pb}$ and organic carbon.

Effect of Cu: Amount of $\mathrm{Cu}$ present in given the samples varies from $1.90 \mathrm{mg} / \mathrm{kg}$ to $48.9 \mathrm{mg} / \mathrm{kg}$. $1.90 \mathrm{mg} / \mathrm{kg}$ is the lowest value in sample S7, and $48.9 \mathrm{mg} / \mathrm{kg}$ be the highest value in sample S4. Positive correlations were observed with $\mathrm{EC}, \mathrm{OC}, \mathrm{Zn}, \mathrm{Pb}$ and $\mathrm{Cr}$, and weak negative correlation with $\mathrm{Cd}(\mathrm{r}=-0.05)$ and a strong negative correlation with Co $(r=0.41)$.

Effect of Cd: Amount of Cd lies between $24.5 \mathrm{mg} / \mathrm{kg}$ and $71.5 \mathrm{mg} / \mathrm{kg}$. Sample S4 gets a higher value $(71.5 \mathrm{mg} / \mathrm{kg})$, and sample $\mathrm{S} 7 \mathrm{a}$ lower value $(24.5 \mathrm{mg} / \mathrm{kg})$. The positive correlation was obtained with $\mathrm{EC}, \mathrm{OC}, \mathrm{Zn}, \mathrm{Pb}$ and $\mathrm{Co}$ whereas a negative correlation with $\mathrm{pH}$ and $\mathrm{Cr}$.

Effect of Cr: Chromium ranges from $0.01 \mathrm{mg} / \mathrm{kg}$ to $41.4 \mathrm{mg} / \mathrm{kg}$. Sample S6 has a least value of $0.01 \mathrm{mg} / \mathrm{kg}$, 
and sample $\mathrm{S} 2$ the highest value. The positive correlation obtained with $\mathrm{pH}, \mathrm{EC}, \mathrm{OC}$ and $\mathrm{Cu}$ but a negative correlation with $\mathrm{Zn}, \mathrm{Pb}$ and $\mathrm{Cd}$ whereas no correlation with $\mathrm{Co}$.

Effect of Co: The values of cobalt in samples vary between $10.5 \mathrm{mg} / \mathrm{kg}$ and $20.8 \mathrm{mg} / \mathrm{kg}$. Sample $\mathrm{S} 1$ has a lower value of $10.5 \mathrm{mg} / \mathrm{kg}$, and sample S6 a higher value $(20.6 \mathrm{mg} / \mathrm{kg})$. A slight positive correlation was observed with $\mathrm{OC}$ and a partial negative correlation with all parameters except $\mathrm{Cr}$ and no correlation with $\mathrm{Cr}$. Abundance of $\mathrm{Co}$ in the soil acts as an inhibitor for soil biological activity (Zaborowska et al. 2016).

\section{CONCLUSION}

It can be thus concluded from the present study that the studied soil samples were slightly-moderately alkaline with moderate SOM. The heavy metal content in the soil is above the trace levels despite intensive anthropogenic practices which can be due to the sandy texture of soil and leaching of metals to lower ground layers. From the analysis of PI, geoaccumulation index and ecological risk factors, soils in all the locations are mainly contaminated and polluted by $\mathrm{Cd}$ followed by $\mathrm{Cu}$ and $\mathrm{Zn}$. The remaining metals moderately influence soil pollution. Major soil pollution control precautions should be taken in stations 4, 5 and 6. Station 7 observed moderate soil contamination of all metals. Multivariate statistical methods applied in this study proved useful in the characterization of heavy metals sources in soils form APIIC zone. Zinc showed excessively high concentrations in the study area. The increasing orders of heavy metals in soils are $\mathrm{Cr}, \mathrm{Co}, \mathrm{Pb}, \mathrm{Cu}, \mathrm{Cd}$ and $\mathrm{Zn}$. Element pairs such as $\mathrm{Zn}-\mathrm{Pb}, \mathrm{Zn}-\mathrm{Cu}, \mathrm{Zn}-\mathrm{Cd}, \mathrm{Pb}-\mathrm{Cu}, \mathrm{Pb}-\mathrm{Cd}, \mathrm{Cu}-\mathrm{Cr}, \mathrm{Cd}-\mathrm{Co}$ and $\mathrm{Cr}-\mathrm{Co}$ showed strong positive correlation indicating their association in the study area. Therefore, measures must be taken to ensure the adoption of more environmentally friendly practices.

\section{REFERENCES}

Anyakora, C., Ehianeta, T. and Umukoro, O. 2013. Heavy metal levels in soil samples from highly industrialized Lagos environment. Afr. J. Environ. Sci. Technol., 7(9): 917-924.

Dara, S. S. and Mishra, D. D. 2006. A Textbook of Environmental Chemistry and Pollution Control. S. Chand Publishing.

Dauda, M. S. and Odoh, R. 2012. Heavy metals assessment of soil in the vicinity of fuel filling station in some selected local government areas of Benue State, Nigeria. Der Chemica Sinica., 3(5): 1329-1336.

USDA 1993. Soil Survey Manual. Soil Survey Division Staff, Washington DC.
Dheri, G. S. Brar, M. S. and Malhi, S. S. 2007. Heavy metal concentration of sewage-contaminated water and its impact on underground water, soil and crop plants in alluvial soils of northwestern India. Commun. Soil. Sci. Plan., 38 (9-10): 1353-1370.

EGASPIN 2002. Environmental Guidelines and Standards for the Petroleum Industry in Nigeria.

Ferner, D. J. 2001. Toxicity, heavy metals. Med. J., 2(5): 1.

Fosmire, G. J. 1990. Zinc toxicity. Am. J. Clin. Nutr.,51(2): 225-227.

Guerra, F. Trevizam, A. R. Muraoka, T. Marcante, N. C. and CanniattiBrazaca, S. G. 2012. Heavy metals in vegetables and potential risk for human health. Sci. Agric., 69(1): 54-60.

Hakanson, L. 1980. An ecological risk index for aquatic pollution control. A sedimentological approach. Water Research, 14(8): 975-1001.

Iwegbue, C. M. A., Bassey, F. I., Tesi, G. O., Nwajei, G. E. and Tsafe, A. I. 2013. Assessment of heavy metal contamination in soils around cassava processing mills in sub-urban areas of Delta State, Southern Nigeria. NJBAS, 21(2): 96-104.

Jacob, H. and Clarke, G. 2002, Methods of Soil Analysis, Part 4, Physical Method. Soil Science Society of America, Inc, Madison, Wisconsin, USA, $1692 \mathrm{p}$.

Jolly, Y. N., Islam, A. and Akbar, S. 2013. Transfer of metals from soil to vegetables and possible health risk assessment. Springer Plus, 2(1): 385-391.

Lacatusu, R. 2000. Appraising levels of soil contamination and pollution with heavy metals. European Soil Bureau, 4: 93-402.

McIntosh, P.D. and Allen, R.B. 1993. Soil pH declines and organic carbon increases under hawkweed (Hieracium pilosella). New Zealand Journal of Ecology, 17(1): 59-60.

Momodu, M. A. and Anyakora, C. A. 2010. Heavy metal contamination of groundwater: The Surulere case study. Res. J. Environ. Earth. Sci., 2(1): 39-43.

Müller, G. 1979. Schwermetalle in den sediments des RheinsVeranderungenseitt 1971. Umschan, 79: 778-783.

Nelson, D. W. and Sommers, L. E. 1982. Methods of Soil Analysis. Part 2. pp. 539-579.

Rajaganapathy, V., Xavier, F., Sreekumar, D. and Mandal, P. K. 2011. Heavy metal contamination in soil, water and fodder and their presence in livestock and products: A review. JEST, 4(3): 234-249.

Rattan, S. S. 2005. Theory of Machines. Tata McGraw Hill Publishing Company Limited. New Delhi.

Tomlinson, D. L., Wilson, J. G., Harris, C. R. and Jeffrey D. W. 1980. Problems in the assessment of heavy-metal levels in the estuaries and the formation of pollution index. Helgol. Mar. Res., 33, 566-575.

Tyler, G., Påhlsson, A. M. B., Bengtsson, G., Bååth, E. and Tranvik, L. 1989. Heavy-metal ecology of terrestrial plants, microorganisms and invertebrates. Water. Air. Soil. Poll., 47(3-4): 189-215.

Ubwa, S. T., Atoo, G. H., Offem, J. O., Abah, J. and Asemave, K. 2013. Effect of activities at the Gboko abattoir on some physical properties and heavy metals levels of surrounding soil. IJC, 5(1): 49.

Underwood, E. J. 1977. Zinc in animal tissues and fluids. Trace elements in human and animal nutrition. In: Trace Elements in Human and Animal Nutrition, 4th Ed., pp. 196-242, Academic Press, New York

Wen, X. and Allen, H. E. 1999. Mobilization of heavy metals from Le An River sediment. Sci. Total. Environ., 227(2-3): 101-108.

Zaborowska, M., Kucharski, J. and Wyszkowska, J. 2016. Biological activity of soil contaminated with cobalt, tin, and molybdenum. Environ. Monit. Asses., 188(7): 398. 